\title{
The Mediating Effect of Intrapreneurship on Concept of Employee Performance
}

\author{
Laili Qomariyah $^{1 *}$, Aning Az Zahra ${ }^{1}$
}

\begin{abstract}
${ }^{1}$ Department of Psychology and Humanities Universitas Muhammadiyah Magelang, Magelang, Indonesia *Corresponding author. Email: laili.qomariyah@ummgl.ac.id
\end{abstract}

\begin{abstract}
Intrapreneurship is the important variable in shaping employee performance better. This study aims to investigate the effect of intrapreneurship as a mediator for job satisfaction and gender on employee performance. The study was conducted using a quantitative approach with a survey method by filled the scale of intrapreneurship scale, job satisfaction scale, and employee performance scale. Number of research subjects are 117 employees who came from many sectors with criteria is employee who work in unit of marketing, sales, and, services. Data analyzed by structural equation modeling (SEM) with the mediation model. The result of the research showed that intrapreneurship is able to be a full mediator of the relationship between gender and employee performance, and gender to be not significant toward employee performance by controlled intrapreneurship. In other hand the researchers also analyzed the relationship between gender toward employee performance without controlled intrapreneurship showed that gender was able to influence employee performance variables significantly. The result confirms that intrapreneurship was able to complete mediator. Also, intrapreneurship can partially mediate the relationship between job satisfaction and employee performance. The practice implication is industry or company able to looking for sales person through recruitment of prospective employee without gender as requirement. Especially is sales person must addition the requirement about intrapreneurship competence in order to able to keep and develop performance of them while recruiting.
\end{abstract}

Keywords: intrapreneurship, gender, job satisfaction, performance

\section{INTRODUCTION}

The existence of increasingly sophisticated technology brings many trends that are starting to shift which also provides business changes significantly. Easy access that can be achieved by humans makes business competition increasingly fierce. This condition drives the business people to continue to have new strategies in order to have high competitiveness. Indicators of good companies are high profit, sales growth rates, and market share [1]. Sales growth rates is a reflection of a company's ability where the higher sales growth, it can be said that the higher the success of a company. An organization to be more competitive must be able to regulate the behavior and output of its resources, especially human resources [2]. It is intended that the company can ensure that each unit will run in accordance with their performance management. This shows that the performance of an employee is crucial about the degree of success a company will achieve. However, there are many companies that still have a requirement and focus to looking for prospective employees with a certain gender as a condition that is part of the company's strategy in improving a performance. In addition, the company is still very focused on a satisfaction that is owned by employees.

Based on point of view Aboazoum et al. [3] that the key of a company's success in achieving its targets and goals lies in employee performance. The results of employee performance appraisal can be used to measure and compare what is expected by the company with what has been done by a sales employee [4]. In addition, employee performance can also be influenced by communication variables [5]. The results of other studies show different things, that performance is able to be influenced by training and development factors, organizational culture, and job satisfaction [3]. Differences in antecedents of performance variables indicate that differences in workplace settings will affect how degrees of performance can be formed.

Several studies have proven that performance can be influenced by several factors. Job satisfaction is able to significantly influence the outcome of their work [6]. This happened both in the manager's level and the workers' group. The same thing was stated by Inuwa that job satisfaction can predict employee performance [7]. The purpose of the performance appraisal is to find out whether an employee is able to achieve the targets given by the company and the results will be related to reward and treatment in the context of career development that will be provided by the organization to its employees [4].

Job satisfaction also affects intrapreneurship. Job satisfaction has a very significant effect on intrapreneurship [8]. In addition, personality (open to new things, cautious nature, extraversion, easy agreement, and neuroticism) is able to mediate the relationship between job satisfaction and intrapreneurship [8]. The statement was reinforced by the research conducted by Friana and Indriana that intrapreneurship affects the company's growth and improvement [9]. Intrapreneurship can be explained by the 
dimensions of innovation, the risk of tendencies in facing new challenges, competitive energy, and proactiveness. Based on that explanation, the researcher wants to examine the dynamics of job satisfaction, performance, and intrapreneurship which are also interrelated for both. Based on the state of the art that has been described, the researcher wants to find out more about the role of intrapreneurship in influencing employee performance improvement. In addition, researcher want to see the relationship between intrapreneurship with other factors that have been proven to affect the level of employee performance, so researcher can build a new knowledge of the role of intrapreneurship in shaping employee performance.

Based on the background that has been explained, the framework of this study is as follows:

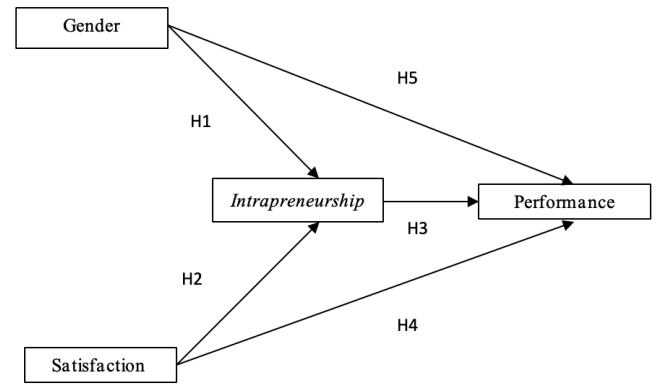

Figure 1 Research framework

In accordance with the research framework in figure 1, the hypotheses of this study are:

H1: Gender is able to effect the intrapreneurship

$\mathrm{H} 2$ : Job satisfaction is able to effect the intrapreneurship

H3: Intrapreneurship is able to effect on employee performance

H4: Job satisfaction is able to effect on employee performance with intrapreneurship as mediator

H5: There is a positive influence of gender on employee performance with intrapreneurship as mediator.

\section{METHODS}

This research is a quantitative research with survey method. Researcher has shared the link of the online questionnaire supported by google form to subject.

\subsection{Instrument}

Instrument in this research is intrapreneurship scale with 8 item that developed by Halabi, Wsquivel, and Siles [10]. Second scale is work performance with 13 item that developed by Pradhan and Jena [11]. Third scale is work satisfaction scale consist of 13 items. Work satisfaction scale developed by Hastuti, Talib, Wong, and Mardani [12]. Overall, that scale is likert scale consist of 5 score, that is 1 for very disagree until 5 score for very agree answer.

\subsection{Research Procedure}

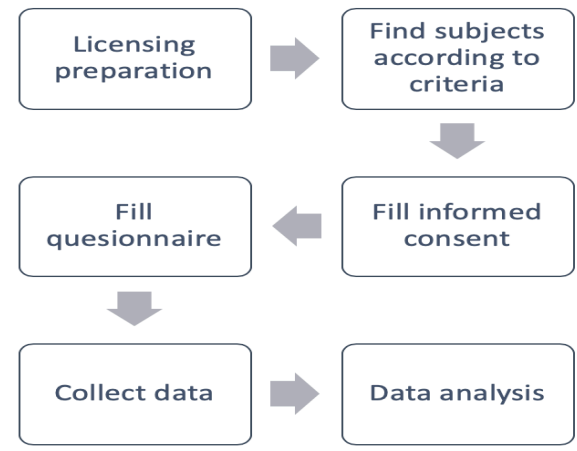

Picture 2 Research procedure

This research begins with licensing preparation and then find the subject for this research. Afterwards subject filled the informed consent and then filled online questionnaire. When the subject is finished and then researcher collect the data and continued to analyze it.

\subsection{Research Subject}

The number of subjects is 130 worker who has specific criteria. that criteria are worker who work in sales or marketing or service unit. Amount of questionnaire that valid is 117 questionnaires.

\subsection{Data Analysis Technique}

Data analysis of this research utilize the Structural Equation Modeling (SEM) with mediation model. Stages of analysis are descriptive test, statistic inferential analysis consisting of parameter significant test, validity test, reliability test, and goodness of fit, and the last stage is hypothesis test.

\section{RESULTS AND DISCUSSION}

Statistical inferential analysis is carried out through 4 stages: 1) parameter significance test, validity test, reliability test, and goodness of fit.

\subsection{Parameter Significant Test}

Table 1 Result of Parameter Significant Test

\begin{tabular}{|llll|}
\hline Scale & Item & C.R. Value & Sig. \\
\hline Intrapreneurship & 8 items & $5,1-6,8$ & 0,000 \\
Satisfaction & 10 items & $4,0-8,3$ & 0,000 \\
Performance & 13 items & $5,7-6,9$ & 0,000 \\
\hline
\end{tabular}

Table 1 shows that all of scale is significant $(p<0,05$ and C.R. $>1,967$ ), so this process is able to continue to validity test process. 3.2. Validity Test 


\subsection{Goodness of Fit}

\begin{tabular}{|lll|}
\hline Scale & Item & Factor loading \\
\hline Intrapreneurship & 8 items & $0,6-0,8$ \\
Satisfaction & 10 items & $0,6-0,9$ \\
Performance & 13 items & $0,6-0,7$ \\
\hline
\end{tabular}

Table 2 shows that all of the scale is valid ( $\mathrm{fl}>0,6$ ), so that scale is able to continue to the next process. 3.3. Reliability Test.

Table 3 Result of Reliability Test

\begin{tabular}{|lll|}
\hline Scale & $\begin{array}{l}\text { Construct } \\
\text { reliability }\end{array}$ & VE \\
\hline Intrapreneurship & 0,83 & 0,9 \\
Satisfaction & 0,83 & 0,99 \\
Performance & 0,9 & 0,9 \\
\hline
\end{tabular}

Table 3 shows that all of the scale is reliable with construct reliability $\geq 0,7$ and $\mathrm{VE} \geq 0,5$.
Table 4 Goodness of Fit

\begin{tabular}{|lll|}
\hline GOFI & Cut off & GOF test \\
\hline GFI & $\geq 0,90$ & 0,999 \\
CFI & $\geq 0,90$ & 1,0 \\
RMSEA & $<0,08$ & 0,000 \\
TLI & $\geq 0.9$ & 1,033 \\
NFI & $\geq 0,9$ & 0,998 \\
AGFI & $\geq 0,90$ & 0,990 \\
RFI & $\geq 0,90$ & 0,990 \\
IFI & $\geq 0,90$ & 1,005 \\
\hline
\end{tabular}

Table 4 shows that the goodness of fit test of the model is a fit model

\subsection{Hypothesis Test}

Table 5 Result of Hypothesis

\begin{tabular}{|c|c|c|c|c|c|}
\hline & Estimate & S.E. & C.R. & $\mathbf{P}$ & Label \\
\hline Intra $<---$ Gender & $-2,289$ &, 600 & $-3,818$ & $* * *$ & par_3 \\
\hline Intra $<---$ satisfaction & 237 & 066 & 3,607 & $* * *$ & par 4 \\
\hline Performance <--- Gender &,- 485 & ,624 &,- 776 & ,483 & par 1 \\
\hline Performance <--- Intra & ,955 & ,091 & 10,482 & $* * *$ & par 5 \\
\hline Performance $<---$ Satisfaction & ,374 & 068 & 5,492 & $* * *$ & par 2 \\
\hline
\end{tabular}

Result of hypothesis test are:

a. Gender is able to effect intrapreneurship significantly with $\mathrm{p}$ value $=0,000$ and C.R. $=-3,818$ (C.R. $>1,967$; $\mathrm{p}<0,05)$. Hypothesis 1 is accepted

b. Work satisfaction is able to effect intrapreneurship significantly with $\mathrm{p}$ value $=0,000$ and C.R. $=3,607$ (C.R. $>1,967 ; p<0,05$ ). Hypothesis 2 is accepted

c. Intrapreneurship is able to effect performance significantly with $\mathrm{p}$ value $=0,000$ and C.R. $=10,482$ (C.R. $>1,967 ; p<0,05)$. Hypothesis 3 is accepted

d. Work satisfaction is able to effect performance significantly with intrapreneurship as moderator. $\mathrm{P}$ value $=0,000$ and C.R. $=5,492$ (C.R. $>1,967$ and $p<0,05$ ). Hypothesis 4 is accepted.

e. Gender is not able to effect performance significantly with intrapreneurship as moderator. $\mathrm{P}$ value $=0,483$ and C.R. $=-, 776$ (C.R. $<1,967 ; \mathrm{p}>0,05$ ). Hypothesis 5 is rejected

Researcher has tested effect of gender to performance independently without intrapreneurship as mediator and satisfaction to performance independently without intrapreneurship as mediator. The result of that test is gender is able to effect performance significantly. The following are the results of the regression test:
Table 6 Result of Regression Test

\begin{tabular}{|lllll|}
\hline & Estimate & S.E. & C.R. & P \\
\hline $\begin{array}{l}\text { Performance } \\
\text { <--- Gender }\end{array}$ & $-2,203$ & 0,962 & $-2,290$ & 0,022 \\
\hline
\end{tabular}

Based on table 5 (with intrapreneurship as a moderator) and table 6 (without intrapreneurship as a moderator) we can see the different them that intrapreneurship is as a full mediator for relationship between gender and performance. That statement supported by p value of table 5 and 6 that in table 5 is not significant and in table 6 is significant.

Table 7 Result of Regression Test

\begin{tabular}{|lllll|}
\hline & Estimate & S.E. & C.R. & P \\
\hline $\begin{array}{l}\text { Performance }<--- \\
\text { Satisfaction }\end{array}$ & 0,576 & 0,094 & 6,138 & $* * *$ \\
\hline
\end{tabular}

Based on table 5 (with intrapreneurship as a moderator) and table 7 (without intrapreneurship as a moderator) we can see the different them that intrapreneurship is as a partial mediator for relationship between satisfaction and performance. That statement supported by $p$ value of table 5 and 7 that in both of table is significant, but in table 5 shows that estimate value in table 7 is higher than table 5 . The results of data analysis prove that performance and gender are predictors in shaping employee performance with intrapreneurship as a mediator. This strengthens the 
performance in Libya,” IOSR J. Bus. Manag., vol. 17, no. 7, pp. 42-49, 2015. satisfaction can be a predictor in shaping performance [6], [7]. This study also provides a more specific study that intrapreneurship is not only able to act as a predictor in a growth and improvement of company performance [9] but also able to act as a mediator for gender relations and job satisfaction with performance.

If drawn to a phenomenon in the company where every company there is always a dynamic regarding employee satisfaction. Not all employees will feel satisfied with their work whether caused by something that can be controlled by the company or not. The efforts that companies can do to improve employee performance are by controlling the role of intrapreneurship as a mediator. Low job satisfaction will have an impact on low employee performance [6], [7], but the impact can be reduced if employees have good intrapreneurship.

\section{CONCLUSION}

Based on the results of the study, the researchers can conclude that intrapreneurship has a large role in shaping and improving employee performance. Companies can improve employee performance through a good intrapreneurship. Low employee satisfaction can still improve employee performance if the company is able to maintain and ensure that an employee has good intrapreneurship. In addition, gender becomes insignificant in efforts to improve company performance provided that the employees of the company have good intrapreneur skills. For further researchers, further research can be conducted on which dimensions of intrapreneurship can improve employee performance in the areas of sales, marketing, and service as a people getting customers for which increases the company's revenue indirectly.

\section{ACKNOWLEDGMENT}

Gratefully acknowledge for open access funding from Universitas Muhammadiyah Magelang, Central of Java, Indonesia through PRVI program.

\section{REFERENCES}

[1] F. A. Zainol, "The antecedents and consequences of entrepreneurial orientation in Malay family firms in Malaysia The antecedents and consequences of entrepreneurial orientation in Malay family firms in Malaysia Fakhrul Anwar Zainol," no. January 2013, 2015.

[2] M. M. Kaswan, Psikologi Industri dan Organisasi. Bandung: Alfabeta, 2017.

[3] H. M. E. Aboazoum, U. Nimran, and M. Al Musadieq, "Analysis factors affecting employees job
[4] B. Kesari, "Salesperson performance evaluation : a systematic approach to salesperson performance evaluation : a systematic approach to refining the sales force," no. December, 2014.

[5] I. Muda, A. Rafiki, and Martua Rezeki Harahap, "Making the link between work-life balance practices and organizational performance. Human Resource Management Review, 19(1), pp.9-22," vol. 5, no. 2, pp. 73-81, 2014.

[6] M Shaju and S. Durai, "A study on the impact of Job Satisfaction on Job Performance of Employees working in Automobile Industry, Punjab, India," J. Manag. Res., vol. 9, no. 1, p. 117, 2017.

[7] M. Inuwa, "Job satisfaction and employee performance: An empirical approach," Millenn. Univ., vol. 1, no. 1, pp. 90-103, 2016.

[8] S. N. Ahmed, A. Rehman, and M. Amjad, "Job Satisfaction and Intrapreneurship: The Moderating Effect of Personality Trait," J. Int. Stud., vol. 6, no. 1, pp. 87-95, 2013.

[9] R. Friana and I. Indriana, "Pengaruh Intrapreneurship Terhadap Kinerja Perusahaan Manufaktur Di Tangerang," J. Manaj., vol. 19, no. 1, p. 14, 2017.

[10] T. V. Halabi, R. M. Esquivel, and B. Siles, "www.econstor.eu," Intrapreneurial competencies Dev. Valid. a Meas. scale, vol. 26, no. 1, pp. 88-111, 2017.

[11] R. K. Pradhan and L. K. Jena, "Employee Performance at Workplace: Conceptual Model and Empirical Validation," Bus. Perspect. Res., vol. 5, no. 1, pp. 69-85, 2017.

[12] A. W. Hastuti, N. B. A. Talib, K. Y. Wong, and A. Mardani, "The Role of Intrapreneurship for Sustainable Innovation through Process Innovation in Small and Medium-sized Enterprises: A Conceptual Framework," Int. J. Econ. Financ. Issues Asia Int. Conf. Int. J. Econ. Financ. Issues, vol. 6, no. Special issue for "Asia International Conference (AIC 205), Kuala Lumpur, Malaysia", pp. 83-91, 2016. 